\title{
PENENTUAN KADAR AIR HILANG DAN VOLATILE MATTER PADA BIO-BRIKET DARI CAMPURAN ARANG SEKAM PADI DAN BATOK KELAPA
}

\author{
YAYAH YULIAH*, SRI SURYANINGSIH, KHOIRIMA ULFI \\ Departemen Fisika Fakultas MIPA Universitas Padjadjaran, \\ Jl. Raya Bandung-Sumedang Km 21, Jatinangor 45363 \\ *email : y.yuliah@phys.unpad.ac.id
}

\begin{abstract}
Abstrak. Sekam padi, sebagai bahan biomassa yang selama ini dibuang atau dibakar sebagai limbah, merupakan sumber karbon potensial yang dapat dimanfaatkan sebagai sumber energi alternatif. Kandungan energinya dapat lebih intensif jika dikemas dalam bentuk yang ringkas dan efisien. Dalam penelitian ini, melalui proses karbonisasi sekam padi dibuat menjadi arang untuk kemudian dikemas dalam bentuk briket. Untuk meningkatkan nilai kalornya diberi campuran arang batok kelapa sebanyak $20 \%$. Tepung tapioka sebagai bahan perekat ditambahkan secara bertahap untuk mendapatkan briket dalam keadaan pejal dengan kandungan nilai kalor maksimum. Penentuan kadar air yang hilang dan nilai volatile matter serta menganalisis pengaruhnya terhadap nilai kalor yang dikandungnya dilakukan untuk mengetahui standar mutu bio-briket yang dihasilkan. Setelah melalui proses kompresi dan pengeringan, diketahui bahwa briket dengan kadar perekat $4 \%$ dan $10 \%$ memiliki kandungan energi panas tertinggi yaitu sebesar $4132 \mathrm{~kJ} / \mathrm{kg}$.
\end{abstract}

Kata kunci : bio-briket, kadar perekat, densitas, nilai kalor

\begin{abstract}
Rice husks as biomass materials that have been discarded or burned as waste, is a potential supply of carbon that can be utilized as an alternative energy source. Energy content can be exploited more intensively if it is packaged in an efficient and convenient form. In this study, through the carbonization process rice husks are made into charcoal for then packaged in the form of briquettes. $20 \%$ of coconut shell charcoal was mixed to increase the calorific value. Tapioca starch as an adhesive was added gradually to obtain briquettes in a solid state with maximum calorific value content. Determination of the value of lost water and volatile matter and analyze the effect on the calorific value it contains was done to evaluate the quality standards of the biobriquettes produced. After going through the compression and drying process, it was identified that the briquettes with adhesive levels of $4 \%$ and $10 \%$ has the highest thermal energy content that is $4132 \mathrm{~kJ} / \mathrm{kg}$.
\end{abstract}

Keywords : bio-briquette, adhesive level, density, calorific value

\section{Pendahuluan}

Produksi padi di Indonesia pada tahun 2015 sebanyak 75,55 juta ton GKG (Gabah Kering Giling) atau mengalami kenaikan sebanyak 4,70 juta ton $(6,64 \%)$ dibandingkan tahun 2014 [1]. Jumlah ini diperkirakan akan terus meningkat seiring dengan upaya intensifikasi produksi padi melalui penerapan berbagai teknologi yang dicanangkan pemerintah. Produksi padi dalam jumlah besar ini juga akan menghasilkan sekam padi yang merupakan salah satu bentuk limbah pertanian yang selama ini hanya digunakan sebagai media tanam atau dibuang dan 
dibakar sebagai sampah. Sebagai bahan biomassa, arang sekam padi merupakan sumber karbon potensial yang dapat dimanfaatkan sebagai bahan bakar dalam skala besar sehingga dapat menjadi salah satu sumber energi alternatif pengganti bahan bakar minyak (BBM)/fosil [2]. Sumber energi alternatif ini dapat memberikan kontribusi terhadap bauran energi primer sebagai pengganti batubara apabila diolah secara optimal.

Pengolahan arang sekam padi menjadi briket merupakan salah satu cara pengemasan sekam padi yang efektif. Briket arang sekam padi dapat menyimpan energi kalor rata-rata sebesar $4384.043 \mathrm{~kJ} / \mathrm{kg}$ [3]. Peningkatan kandungan energi briket arang sekam padi dapat dilakukan dengan menambahkan jenis biomassa lain dengan nilai energi kalor yang tinggi. Sebagai contoh energi kalor rata-rata briket arang sekam padi bertambah menjadi $4526.097 \mathrm{~kJ} / \mathrm{kg}$ setelah diberi campuran arang kayu [3]. Peningkatan kualitas briket dapat dilakukan pada tahap penyiapan arang dimulai dari proses karbonisasi, penghalusan, penentuan komposisi dan penambahan bahan perekat yang tepat dengan kadar yang tepat pula.

Untuk menganalisis nilai kalor dari briket yang dihasilkan antara lain dapat dilakukan melalui uji kadar air yang hilang karena proses pemanasan. Penentuan kadar air yang hilang (\%) dilakukan menggunakan persamaan (1) sebagai berikut,

$$
K A_{\text {hilang }}(\%)=\frac{m_{1}-m_{2}}{m_{1}} \times 100 \%
$$

Dimana $m 1$ (g) adalah massa briket setelah dikompresi atau sebelum pemanasan, $m 2(\mathrm{~g})$ adalah massa briket setelah pemanasan.

Nilai kadar air yang hilang ini juga akan mempengaruhi densitas/kerapatan briket yang dapat ditentukan dengan menggunakan persamaan (2),

$$
\rho=M V
$$

dimana $M$ adalah massa briket setelah dikeringkan (gr), dan $V$ adalah volume briket $\left(\mathrm{cm}^{3}\right)$.

Kadar air suatu bahan arang antara lain tergantung pada kadar silika yang dikandungannya yang bersifat menyerap air. Kandungan silika pada arang sekam padi adalah $16.98 \%$ sedangkan pada arang tempurung kelapa adalah 52\% [4]. Kandungan silika ini juga akan menambah kandungan volatile matter pada sebuah briket. Menurut hasil penelitian Prof. Dr. Muhammad Zarlis, M.Sc dkk. pada tahun 2009 menyatakan bahwa semakin banyak kandungan silika pada suatu briket maka semakin banyak kandungan volatile matter-nya. Volatile matter atau zat terbang adalah zat yang dapat menguap sebagai hasil dekomposisi senyawasenyawa yang masih terdapat di dalam briket selain air, karbon terikat dan abu [5]. Tinggi rendahnya kadar zat menguap/volatile matter pada briket disebabkan oleh kesempurnaan proses karbonisasi dan juga di pengaruhi oleh waktu dan suhu pada proses pengarangan. Semakin besar suhu dan waktu pengarangan maka semakin banyak zat menguap terbuang sehingga pada saat pengujian kadar zat menguap akan diperoleh kadar zat menguap yang rendah, besarnya ditentukan dengan menggunakan persamaan (3), 


$$
V M(\%)=\left[m_{3}-m_{4} / m_{2}-m_{1}\right] \times 100
$$

dimana: $\mathrm{m} 1=$ mangkuk kosong, $\mathrm{m} 2=$ mangkuk kosong + sampel, $\mathrm{m} 3=$ mangkuk kosong + sampel setelah dipanaskan, $\mathrm{m} 4=$ mangkuk kosong + sampel setelah pendinginan.

Penambahan perekat pada suatu briket juga dapat mempengaruhi kadar air yang dikandungnya. Keberadaan kanji sebagai perekat misalnya akan menambah kandungan air dari arang karena kanji dan arang sama-sama tidak tahan terhadap kelembaban sehingga mudah menyerap air dari udara [6].

Penentuan standar mutu briket yang lebih lengkap dilakukan melalui uji proksimate yang meliputi antara lain [7]:

a. Uji Kandungan Air.

Peningkatan kadar air akan mengurangi suhu pembakaran maksimum adiabatik dan meningkatkan waktu yang diperlukan untuk pembakaran yang sempurna dalam tungku. Kadar air biomassa memiliki kepentingan besar dalam hal daya tahan penyimpanan, nilai kalor bersih, pengapian diri, perancangan pabrik, perhitungan jumlah untuk konsumsi boiler. Hasil uji kandungan air ini dapat juga digunakan untuk karakterisasi lain misalnya untuk menentukan air-dry moisture loss.

b. Uji Kandungan Volatile Matter (Zat Terbang).

Bertujuan untuk mengetahui kandungan zat terbang dalam briket yang dihasilkan. Nilai volatile matter ini berpengaruh terhadap kesempurnaan pembakaran dan nyala api yang dihasilkan yang dapat menentukan daya jual briket.

c. Uji Kandungan Abu.

Dilakukan untuk mengetahui kadar abu yang dihasilkan setelah briket mengalami pembakaran. Kandungan abu biomassa adalah residu dari sisa pembakaran yang bersifat tidak mudah terbakar. Ini merupakan mineral massal setelah karbon, oksigen, sulfur dan udara yang telah terjadi selama proses pembakaran.

d. Penentuan Fixed Carbon.

Bertujuan untuk mengetahui kadar karbon terikat yang terkandung dalam briket

Hasil uji proksimate ini akan mempengaruhi nilai energi kalor dari sebuah briket. Kadar air, volatile matter dan kadar abu yang semakin tinggi akan mengakibatkan nilai energi kalor yang semakin rendah dan sebaliknya kualitas briket yang baik memiliki kandungan air, volatile matter dan abu yang sedikit. Sedangkan kadar fixed carbon yang semakin tinggi akan membuat nilai kalor briket yang semakin tinggi.

Pada penelitian ini dilakukan pembuatan bio-briket arang sekam padi dengan menambahkan $20 \%$ arang tempurung kelapa untuk meningkatkan nilai kalornya sebagai pengganti arang kayu yang sudah jarang ditemui serta tidak menguntungkan secara ekonomis. Tepung kanji digunakan sebagai bahan perekat 
karena mudah terbakar dan menghasilkan kalor yang tinggi [8]. Pengukuran kadar air yang hilang dan volatile matter dilakukan untuk menganalisis nilai kalor yang dihasilkan.

Melalui pembuatan dan uji karakteristik bio-briket berbahan dasar arang sekam padi ini diharapkan dapat diperoleh pemahaman tentang mekanisme pembuatan bio-briket dari campuran arang sekam padi dan arang tempurung kelapa serta dapat memberikan kontribusi tentang cara pemanfaatan limbah sekam padi sebagai sumber energi alternatif pengganti bahan bakar fosil (batu bara).

\section{Metode Penelitian}

Bahan utama yang digunakan dalam penelitian ini adalah sekam padi, tempurung kelapa dan tepung tapioka. Alat yang digunakan terdiri dari pemanas, penghalus, saringan, cetakan briket dan alat kompresi briket.

Proses penyiapan bahan dilakukan terutama untuk mendapatkan arang sekam padi sedangkan arang tempurung kelapa menggunakan yang tersedia dipasaran. Sebelum dibuat arang, sekam padi dijemur selama 10-15 jam lalu disangrai sampai hitam untuk kemudian didinginkan.

Proses berikutnya adalah pengecilan ukuran, arang sekam padi dihaluskan dengan menggunakan blender sedangkan arang tempurung kelapa dengan cara ditumbuk. Secara terpisah kedua bahan tersebut disaring menggunakan saringan berukuran 120 mesh.

Selanjutnya disiapkan campuran arang sekam padi dan tempurung kelapa dengan komposisi $80 \%$ arang sekam padi $20 \%$ arang tempurung kelapa. Pada arang campuran ini ditambahkan bahan perekat berupa tepung kanji dengan 4 variasi $\%$ massa masing-masing $4 \%, 6 \%, 8 \%$ dan $10 \%$.

Bahan pembuat briket dibuat dari 80 gram arang campuran biomassa dan bahan perekat yang terdiri dari $60 \mathrm{ml}$ air serta bahan perekat kanji sesuai dengan variasi persentase massanya. Bahan perekat terlebih dahulu disiapkan dengan mencampurkan kanji dengan air dalam sebuah wadah, kemudian dipanaskan di atas kompor sambil diaduk hingga mengental. Campuran arang biomassa kemudian dimasukkan dan diaduk hingga homogen. Adonan selanjutnya dimasukkan kedalam cetakan berbentuk silinder kemudian dilakukan pengepresan menggunakan alat kompresi hidrolik dengan kekuatan 3 ton. Briket yang telah dicetak dikeringkan di dalam oven pada temperatur $55^{\circ} \mathrm{C}$ selama 24 jam. Proses pengeringan ini dilakukan untuk mengurangi kandungan air dalam briket, sehingga mudah menyala pada saat dibakar.

Selain penentuan nilai kalor, karakterisasi briket yang dilakukan meliputi penentuan kadar air yang hilang pada proses pemanasan dan uji kandungan volatile matter atau zat terbang.

Penentuan kadar air yang hilang dari setiap sampel dilakukan dengan menggunakan persamaan (1). Penentuan Volatile Matter (Zat Terbang) dilakukan di Lab. Batubara PUSLITBANG TEKMIRA Bandung. Uji nilai kalor bio-briket yang dihasilkan dilakukan dengan menggunakan bom calorimeter. Pengujian dilakukan di Lab. Batubara PUSLITBANG TEKMIRA Bandung. 


\section{Hasil dan Pembahasan}

Telah dibuat bio-briket dari campuran arang sekam padi dan batok kelapa dengan komposisi 80\%:20\%. Pada campuran ini ditambahkan tepung kanji sebagai bahan perekat dengan 4 variasi konsentrasi (\% massa) 4\%, 6\%, 8\% dan 10\% sehingga diperoleh empat varian bio-briket arang sekam padi-batok kelapa berbentuk silinder dengan ukuran luas permukaan $3,14 \mathrm{~cm}^{2}$ dan tinggi rata-rata $1,85 \mathrm{~cm}$ 2,31 cm seperti pada Gambar 1 .

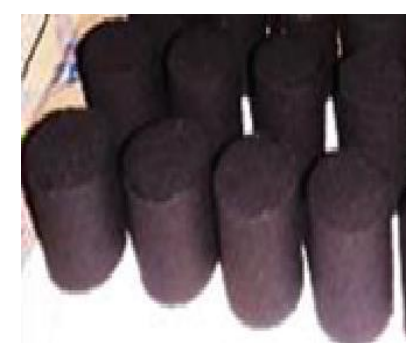

Gambar 1. Bio-briket Sekam Padi-Batok Kelapa

Tabel 1. Kadar Air yang Hilang

\begin{tabular}{cccc}
\hline Sampel & $\begin{array}{c}\text { Kadar Perekat } \\
(\%)\end{array}$ & $\rho\left(\mathrm{g} / \mathrm{cm}^{3}\right)$ & $K A(\%)$ \\
\hline A & 4 & 0.76 & 36.01 \\
B & 6 & 0.68 & 37.70 \\
C & 8 & 0.78 & 35.42 \\
D & 10 & 0.84 & 28.56 \\
\hline
\end{tabular}

Hasil penentuan volatile matter untuk setiap sampel bio-briket dapat dilihat pada Tabel 2. Pada tabel tersebut tampak bahwa nilai volatile matter tergantung pada kadar kanji. Semakin tinggi kadar kanji semakin besar nilai volatile matter yang dikandungnya. Ini terjadi karena adanya zat-zat menguap yang dikandung oleh perekat, seperti $\mathrm{CO}, \mathrm{CO}_{2}, \mathrm{H}_{2}$ dan $\mathrm{CH}_{4}$ [5]. Semakin tinggi kadar kanjinya maka kandungan zat-zat tersebut semakin bertambah. Kadar volatile matter yang paling tinggi berada pada sample D yaitu sebesar $25,61 \%$ dan kadar terendah pada sampel A yaitu sebesar 21,88\%.

Kadar volatile matter yang dihasilkan dari penelitian ini belum memenuhi standar yang telah ditentukan oleh pemerintah yaitu Peraturan Menteri Energi dan Sumber Daya Mineral Republik Indonesia (ESDM RI) No. 047 Tahun 2006, dimana kadar volatile matter maksimal yang boleh dimiliki briket arang adalah $15 \%$, sedangkan briket hasil penelitian memiliki kadar air berkisar 21,70\% - 25,61\%.

Tabel 2. Kadar Volatile Matter

\begin{tabular}{ccc}
\hline Sampel & $\begin{array}{c}\text { Kadar Perekat } \\
(\%)\end{array}$ & $\begin{array}{c}\text { Kadar Volatile } \\
\text { Matter }(\%)\end{array}$ \\
\hline A & 4 & 21,88 \\
B & 6 & 21,91
\end{tabular}




\begin{tabular}{ccc}
$\mathrm{C}$ & 8 & 22,63 \\
$\mathrm{D}$ & 10 & 25,61 \\
\hline
\end{tabular}

Tabel 3. Nilai Kalor Rata-rata

\begin{tabular}{cccc}
\hline Sampel & $\begin{array}{l}\text { Kadar } \\
(\%)\end{array}$ & Perekat & Q (cal/gr) \\
\hline A & 4 & 4124 \\
B & 6 & 4132 \\
C & 8 & 4104 \\
D & 10 & 4132 \\
\hline
\end{tabular}

Meskipun memiliki nilai volatile matter paling tinggi dibandingkan sampelsampel lainnya sesuai dengan kadar perekatnya yang juga paling tinggi, sampel D memiliki nilai kalor yang sama dengan sampel B yang kadar perekatnya lebih rendah. Volatile matter umumnya terdiri dari komposisi methane, hydrocarbons, hydrogen dan carbon monoxide, dan gas tidak mudah terbakar seperti carbon dioxide dan nitrogen, berarti volatile matter bisa memudahkan proses pembakaran bio-briket atau sebaliknya, tergantung pada komposisi zat yang dikandungnya yang tidak bisa terbakar.

\section{Kesimpulan}

Telah berhasil dilakukan pembuatan bio-briket dari campuran arang sekam padi dan arang tempurung kelapa. Meskipun dari nilai volatile matter-nya belum memenuhi standar Menteri ESDM RI No. 047 Tahun 2006, tetapi nilai kalornya sudah mencapai lebih dari 50\% nilai kalor batubara. Sampel-B dengan kadar perekat $6 \%$ merupakan sampel dengan nilai kalor tertinggi. Melihat kerapatannya yang jauh lebih rendah dibandingkan sampel-D yang memiliki nilai kalor yang sama, nilai kalor sampel-B masih dapat ditingkatkan dengan proses kompresi yang lebik kuat.

\section{Daftar Pustaka}

1. Mukti, Hafidz. 2015. Produksi Padi 2015 Tertinggi dalam 10 Tahun Terakhir. Online. http://www.cnnindonesia.com/ekonomi/20150702060011-9263751/produksi-padi-2015-tertinggi-dalam-10-tahun-terakhir/, diakses pada 13-09-2015 pukul 21.50.

2. Nur, Syukri M. 2014. Karakteristik Limbah Padi Sebagai Bahan Baku Bioenergi. Bogor: PT Insan Fajar Mandiri Nusantara.

3. Soelaiman, Jalal Rosyidi. 2013. Perbandingan Karakteristik Antara Briketbriket Berbahan Dasar Sekam Padi Sebagai Energi Terbarukan (skripsi). Jurusan Fisika Fakultas Matematika dan Ilmu Pengetahuan Alam Universitas Jember.

4. Yokoyama, Shinya (ed.), dkk. 2008. Panduan untuk Produksi dan Pemanfaatan Biomassa. Jepang: The Japan Institute of Energy. 
5. Warman, Aditia. 2005. Analisa Pengaruh Impregnesi Silika (SiO2) terhadap Nilai Kalor Bakar dan Kuat Tekan Briket Arang Tempurung Kelapa (tesis). Sekolah Pascasarjana Universitas Sumatera Utara Medan.

6. Gandhi B, Aquino. 2010. Pengaruh Variasi Jumlah Campuran Perekat Terhadap Karakteristik Briket Arang Tongkol Jagung (paper). Jurusan Kimia Fakultas MIPA Universitas Hasanudin.

7. A.Simorangkir, Tiffani. 2014. Analisa Proximate, Analisa Ultimate dan Analisa Miscellaneous pada Batubara (skrispi). Jurusan Teknik Pertambangan Fakultas Teknik Pertambangan Institut Teknologi Medan.

8. Maryono dkk. 2013. Pembuatan dan Analisis Mutu Briket Arang Tempurung Kelapa Ditinjau dari Kadar Kanji (paper). Jurusan Kimia FMIPA Universitas Negeri Makasar. 